\title{
Acute Immunologic Pulmonary Alveolitis
}

\author{
Kent J. Johnson and Peter A. Ward \\ From the Department of Pathology, University of Connecticut Health Center, \\ Farmington, Connecticut 06032
}

\begin{abstract}
A в S T RACT Acute immunologic injury of rat lung has been induced by the intrabronchial injection of heterologous antibody and the intravenous injection of radiolabeled antigen. Within $4 \mathrm{~h}$ an acute hemorrhagic neutrophil-rich exudate develops in alveolar and interstitial areas and then gradually fades. Lung injury in this model can be quantitated by measurements of increased vascular permeability and extractable hemoglobin. By the use of immunofluorescent techniques, alveolar and interstitial deposits of antigen and antibody have been demonstrated, but not the third component of complement (C3). Although not found in relation to immune complexes, C3 is nevertheless present in damaged lung as measured by accumulation of radiolabeled C3 from the circulation. Ablation experiments indicate the requirement for both circulating neutrophils and C3 for the development of lung injury. These studies provide definition for the development of lung damage induced by immune complexes.
\end{abstract}

\section{INTRODUCTION}

In order to gain better insight into the many types of pulmonary inflammatory diseases which afflict man and are presumed to have an immunological basis, several experimental approaches using animal models have been studied. In general these models of immunologic lung injury can be divided into those that feature antibody specific to native lung antigens and those that are mediated by immune complexes. To what extent a third mechanism, cell-mediated immunity, may play a role in the various types of lung injury is not known. The general subject of immunologically induced lung injury has been recently reviewed $(1,2)$.

Studies utilizing heterologous lung-specific antibody have demonstrated that the primary morphologic finding is focal perivascular hemorrhage of quite limited duration $(3,4)$. This experimental model has been somewhat disappointing in terms of recognizable rele-

Received for publication 31 Jamuary 1974 and in revised form 12 April 1974. vance to human pulmonary diseases except, possibly, in the case of pulmonary hemorrhage associated with Goodpasture's syndrome (5). Another approach to the study of immunologic lung diseases has involved active sensitization of animals, followed by administration of antigen via intrapulmonary (transbronchial) passage or intravenous challange. With actively sensitized animals it becomes very difficult to discern the immunological mechanism of tissue injury, but it has been assumed that in most cases immune complexes are involved (6-12). In several of these studies massive amounts of antigen, much of it in crude form, have been introduced intrabronchially, making the results difficult to interpret. In none of the studies cited above has it been possible to obtain precise quantitative data that reflect the degree of tissue injury. Furthermore, few, if any, of the studies have delineated the mediator systems responsible for the ensuing tissue injury.

In this report we describe a model of experimentally induced immunologically dependent pulmonary damage produced by immune complexes. The acute inflammatory reaction in pulmonary alveoli has been quantitated by the use of radioactive markers. In addition, mediator systems essential for the development of lung injury have been determined. This model may serve as a basis for the systematic study of immune complex-induced injury of the lung.

\section{METHODS}

Animals. Adult male, Long Evans rats weighing approximately $300 \mathrm{~g}$ were used as the experimental subjects.

Experimental procedures. When pulmonary reactions were induced, the antibody (present as the rabbit IgG fraction which was rich in antibody to bovine serum albumin $\left.[\mathrm{BSA}]^{1}\right)$ (13) was injected into the bronchial tree by tracheostomy performed under ether anesthesia. Through the lumen of a no. 17 needle inserted into the trachea a polyethylene catheter with a caliber of $1 \mathrm{~mm}$ was passed into the bronchial tree and the antibody injected during inspiration. The catheter and needle were

${ }^{1}$ Abbreviations used in this paper: BSA, bovine serum albumin; PMN, polymorphonuclear leukocyte. 


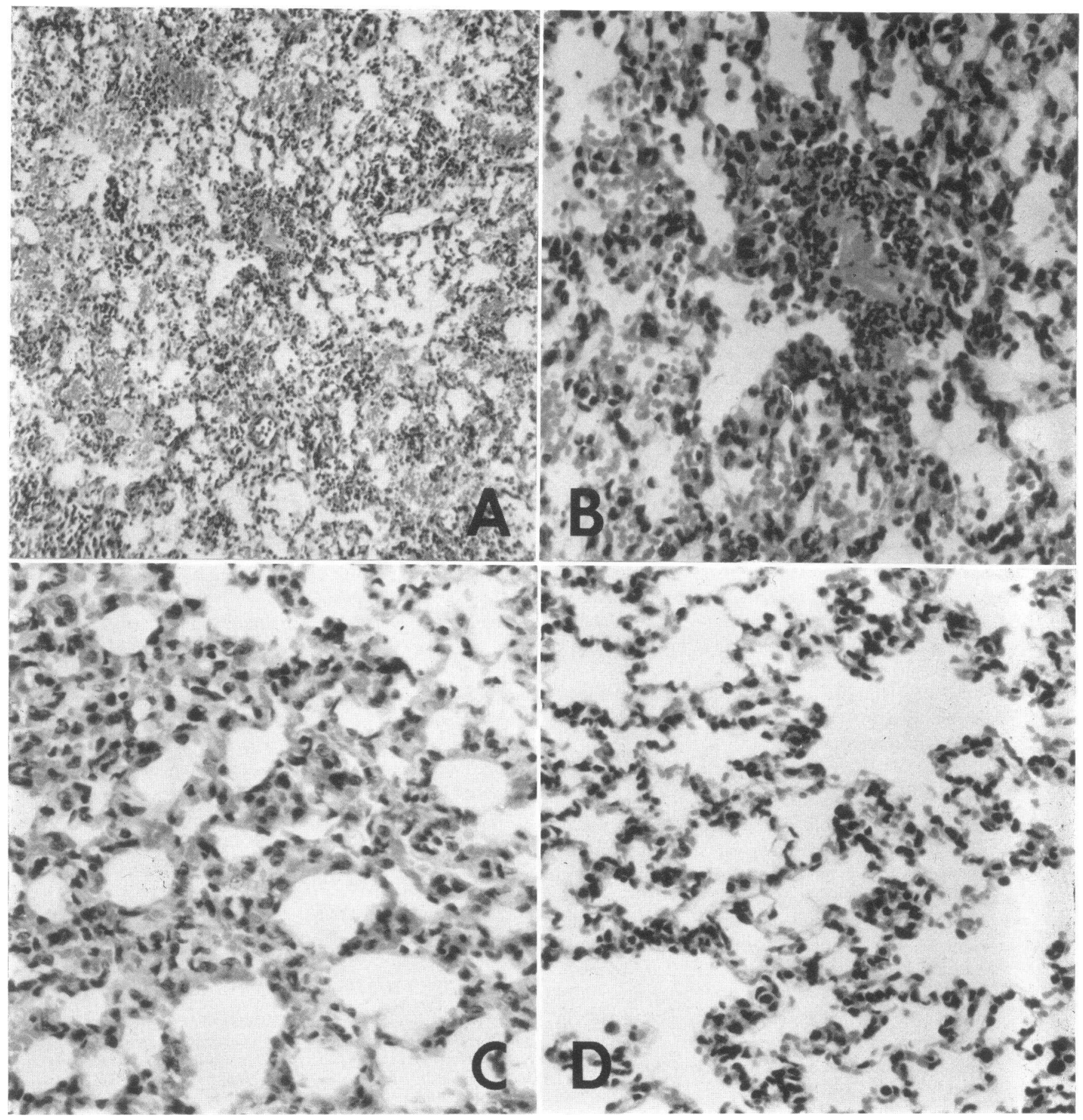

FIGURE 1 Histologic features of the pulmonary reaction in a positive, control animal (A). There is extensive intra-alveolar accumulations of protein, red cells and neutrophils. At a higher magnification, neutrophils are present in alveolar septal walls (B). The reaction in a complement-depleted rat (C) reveals few cells or protein material in alveolar spaces, with slightly increased interstitial cellularity. A section of normal rat lung is shown for comparison (D). (Sections were formalin fixed and stained with hematoxylin and eosin. Magnification: $40,120,40,40 \times$, respectively for A-D.) 
TABLE I

Dependence of Lung Permeability Changes on Specific Antibody

\begin{tabular}{ccc}
\hline $\begin{array}{c}\text { Animal group } \\
\text { (Nature of IgG) }\end{array}$ & $n$ & $\begin{array}{c}\text { Permeability } \\
\text { changes* }\end{array}$ \\
\hline Normal rabbit IgG & 5 & $0.27 \pm 0.12 \ddagger$ \\
Rabbit anti-BS. & 5 & $1.32 \pm 0.34$
\end{tabular}

* Measured as the amount of radioactivity in lung lobes relative to the amount of radioactivity in $1.0 \mathrm{ml}$ blood obtained at the time of sacrifice. The numbers represent milliliter equivalents of radioactivity present in the blood.

¥ Standard error of the mean in this and all subsequent tables.

then withdrawn. Antibody in a total volume of $0.25 \mathrm{ml}$. containing $250 \mu \mathrm{g}$ antibody nitrogen (as precipitating antibody), was used. Controls for the experimental group consisted of rats similarly treated, but injected intrabronchially with $0.25 \mathrm{ml}$ of rabbit IgG lacking in antibody to BSA (but containing the same total amount of protein), or rats injected intrabronchially with $0.25 \mathrm{ml}$ saline. Immediately after the transtracheal intrabronchial injections, $10 \mathrm{mg}$ BSA was injected intravenously via a foot vein. When radiolabeled BSA was used, a trace amount was mixed with the nonlabeled BSA before injection. The BSA was radiotagged with ${ }^{125} \mathrm{I}$ such that each protein molecule contained an average of $\frac{1}{2}$ molecule of ${ }^{125} \mathrm{I}$. The lung reactions were permitted to develop over the course of several hours. At the time of sacrifice, the pulmonary vasculature was perfused with $5 \mathrm{ml}$ saline injected into the right ventricle of the heart so that blood-associated radioactivity in the pulmonary vasculature would be removed. In some experiments two protein markers were used, one labeled with ${ }^{1: 11} \mathrm{I}$, the other with ${ }^{125} \mathrm{I}$. Iodination was performed by the iodine monochloride method (14). The proteins included BSA, human $\operatorname{IgG}$, and rat $\mathrm{C} 3$ purified in the same manner as human C3 (15). Briefly, C3 was isolated by isoelectric precipitation, ion exchange chromatography, hydroxyl apatite chromatography, and preparative electrophoresis. The resultant preparation vielded a single band in analytical polyacrylamide electrophoresis. Approximately $1 \mu \mathrm{Ci}$ radioactivity was injected into each rat.

When lung homogenates were studied for hemoglobin content, lung tissues were homogenized with a Virtis in-

TABLE II

Comparison of Permeability Changes in Lungs, Using Two Different Proteins

\begin{tabular}{|c|c|c|c|}
\hline \multirow[b]{2}{*}{ Animal groups } & \multirow[b]{2}{*}{$n$} & \multicolumn{2}{|c|}{ Permeability changes* } \\
\hline & & BSA & $\operatorname{IgG}$ \\
\hline $\begin{array}{l}\text { Controls (saline } \\
\text { into lungs) }\end{array}$ & 4 & $0.37 \pm 0.07$ & $0.36 \pm 0.02$ \\
\hline $\begin{array}{l}\text { Experimental (antibody } \\
\text { into lungs) }\end{array}$ & 4 & $0.70 \pm 0.07$ & $0.76 \pm 0.09$ \\
\hline
\end{tabular}

* As measured by the accumulation in lungs of [ $\left.{ }^{125} \mathrm{I}\right] \mathrm{BSA}$ and ${ }^{131}$ I] IgG (human) which had been simultaneously given intravenously.
TABLE III

Time-Course in Permeability Changes in Rat Lungs

\begin{tabular}{|c|c|c|c|c|c|}
\hline \multirow[b]{3}{*}{ Animal groups } & \multicolumn{5}{|c|}{ Permeability change:* } \\
\hline & \multicolumn{5}{|c|}{ Hour: after injection of reactants } \\
\hline & 3 & 5 & 24 & 48 & 96 \\
\hline \multirow[t]{5}{*}{$\begin{array}{l}\text { Controls (saline } \\
\text { into lungs) }\end{array}$} & 0.14 & 0.36 & 0.30 & 0.34 & 0.30 \\
\hline & & 0.28 & 0.22 & 0.30 & 0.30 \\
\hline & & 0.22 & & & \\
\hline & & 0.14 & & & \\
\hline & & 0.28 & & & \\
\hline \multirow[t]{4}{*}{$\begin{array}{l}\text { Experimentals (anti- } \\
\text { body into lungs) }\end{array}$} & 0.54 & 0.81 & 0.58 & 0.30 & 0.36 \\
\hline & 0.81 & 0.94 & 0.54 & 0.34 & 0.46 \\
\hline & & 0.81 & 0.58 & & \\
\hline & & 0.87 & & & \\
\hline
\end{tabular}

* Accumulation of radiotagged BSA in lung tissues, expressed as milliliter equivalents of blood radioactivity, as in Tables I and II. Each number represents a different animal.

strument (16). The lipid-rich supernate obtained after centrifugation of the homogenate at $20,000 \mathrm{~g}$ for $15 \mathrm{~min}$ was then passed through a Millipore filter (pore size of 0.4 $\mu \mathrm{m})$ and the solution read in a Gilford microsample $300 \perp$ spectrophotometer (Gilford Instrument Laboratories, Inc., Oberlin, Ohio) at $415 \mathrm{~nm}$. Immunofluorescent microscopy was carried out by using the direct technique, according to previously reported procedures (13).

Arthus rcactions. These reactions were induced by the intradermal injections of the $100 \mu \mathrm{g}$ antibody $N$ to BSA (see above) and the systemic injection of $10 \mathrm{mg}$ BSA to which radiotagged $\mathrm{BSA}$ had also been added (see above).

TABLE IV

Localization of Reactants by Immunofuorescence

\begin{tabular}{|c|c|c|c|c|}
\hline \multirow{2}{*}{$\begin{array}{l}\text { Time of } \\
\text { reaction }\end{array}$} & \multirow{2}{*}{$\begin{array}{l}\text { Animal } \\
\text { number }\end{array}$} & \multicolumn{3}{|c|}{ Proteins localized in tis:sue:* } \\
\hline & & Rabbit IgG & BS.A & Rat $\mathrm{C} 3$ \\
\hline \multicolumn{5}{|l|}{$h$} \\
\hline \multirow[t]{2}{*}{3} & 1 & $3+$ & $2+$ & neg \\
\hline & 2 & $3+$ & $3+$ & ney \\
\hline \multirow[t]{5}{*}{5} & 3 & $3+$ & $4+$ & neg \\
\hline & 4 & $3+$ & $4+$ & neg \\
\hline & 5 & $4+$ & $3+$ & neg \\
\hline & 6 & $2+$ & $4+$ & neg \\
\hline & 7 & $3+$ & $3+$ & negr \\
\hline \multirow[t]{2}{*}{8} & 8 & trace & $3+$ & negr \\
\hline & 9 & neg & neg & neg \\
\hline \multirow[t]{2}{*}{20} & 10 & neg & neg & neg \\
\hline & 11 & neg & neg & neg \\
\hline
\end{tabular}

* Rated in terms of intensity on an arbitrary scale, 1 to $4+$, according to reference 13 .

Acute Immunologic Pulmonary Alveolitis 


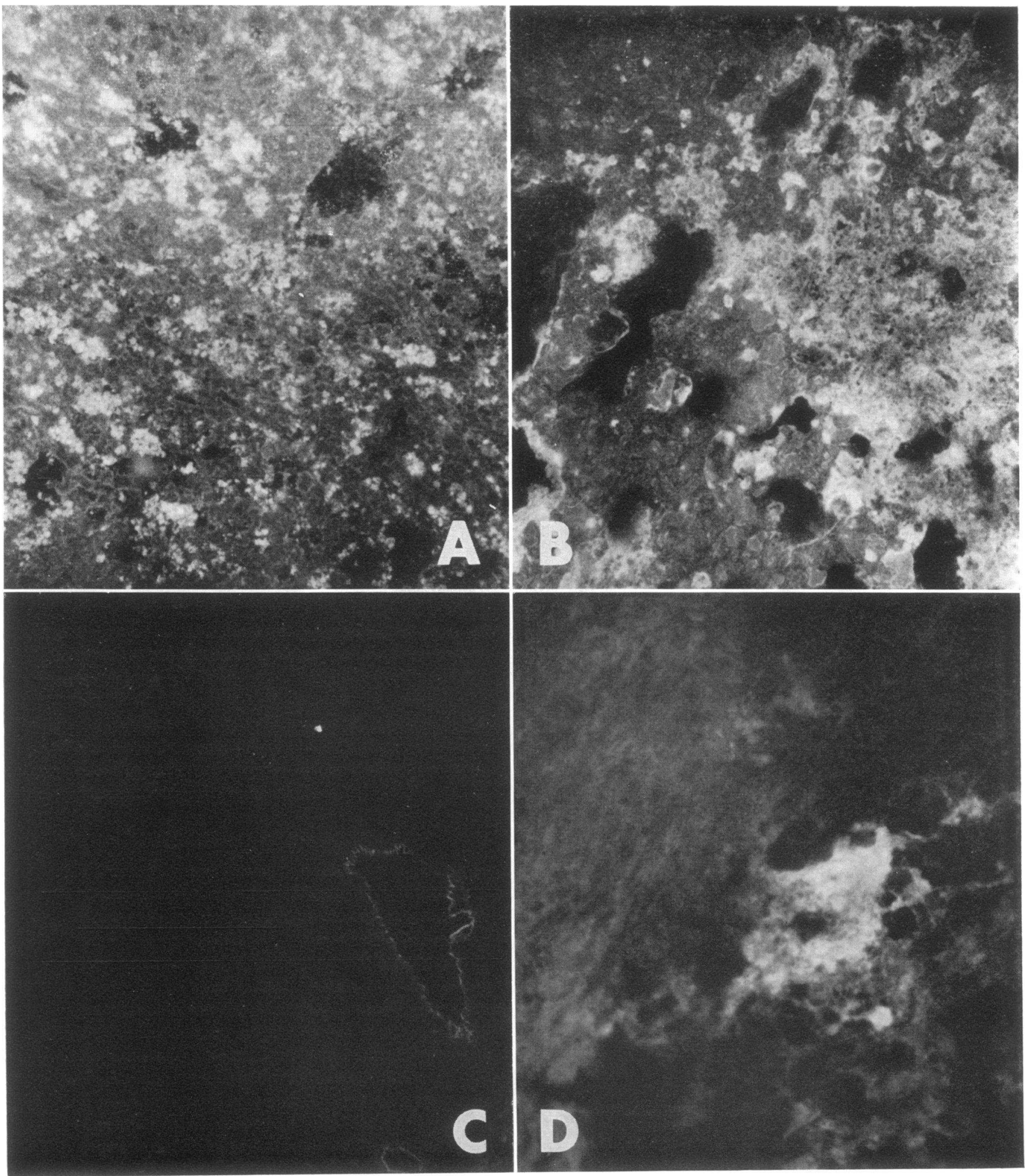

FIGURE 2 Immunofluorescent studies in a normal, complement-intact rat. Localization of the intravenously injected antigen, BSA, shown in (A), is granular, irregular and diffuse, apparently in alveolar spaces. Antibody (rabbit IgG) (B), shows a similar but slightly less well defined distribution. No $\mathrm{C} 3$ is demonstrable in serial sections of lung reactions $(C)$, where autofluorescing elastic laminae of arterioles are seen. A dermal Arthus reaction in the same animal at the same interval $(3 \mathrm{~h})$ demonstrates the presence of $\mathrm{C} 3$ in the wall of a small blood vessel. (A, B, and D are $40 \times$ magnifications; $C$ is $150 \times$.) 
Biopsies of Arthus sites were obtained 3-5 h later, depending on the experimental protocol.

Preparation of C3 inactivator. This was isolated from crude cobra venom according to the procedure of Ballow and Cochrane (17). Rats received $250 \mathrm{U}$ of the $\mathrm{C} 3$ inactivator over a period of 2 days, sufficient to cause disappearance of the $\mathrm{C} 3$ band when sera were tested by double diffusion in gel by using rabbit antibody to rat $\mathrm{C} 3$ (18).

Neutrophil depletion. This was carried out by using rabbit antibody to rat neutrophils. The preparation was described previously (13). Treatment was sufficient to produce a neutrophil count of $<500$ cells $/ \mathrm{mm}^{3}$ blood. Under such conditions, Arthus reactions were totally suppressed both grossly and histologically.

Permeability changes. These were measured by the accumulation of either radiotagged BSA or human $\mathrm{IgG}$ in lobes of lungs in which vasculatures were perfused with 5 $\mathrm{ml}$ saline at the time of sacrifice (see above). At this point the perfusion fluid was clear and colorless. In each milliliter of this fluid less than $1 \%$ of the radioactivity present in $1 \mathrm{ml}$ blood could be measured. Permeability was expressed as the amount of radioactivity accumulating in lung tissue relative to the amount of radioactivity present in $1 \mathrm{ml}$ blood removed at the time of sacrifice.

Radioactivity measurements. A deep well scintillation counter (Nuclear-Chicago Corp., Des Plaines, Ill.) instrument was used. In some experiments appropriate settings were used so that simultaneous counting of ${ }^{125} \mathrm{I}$ and ${ }^{131} \mathrm{I}$ could be accomplished.

\section{RESULTS}

Gross and histologic features of pulmonary reactions. Within $5 \mathrm{~h}$ after intrabronchial and intravenous injection of the respective reactants, acute hemorrhagic reactions developed in the lungs. Grossly, these reactions varied from diffuse focal hemorrhages in dependent areas of supine rats (right upper, right lower, and left upper lobes) to confluent hemorrhages, especially prominent in the right lower lobes. Lung consistency was markedly increased in such cases. In animals injected with saline or rabbit IgG devoid of antibody activity to BSA the lobes of lung appeared grossly normal, except for local atelectactic changes in the right lower lobe. Histologically, changes were striking in the positive control animals which received antibody intrabronchially and antigen intravenously. There was evidence of an acute hemorrhagic alveolitis, with large numbers of neutrophils in alveolar septal walls. While less prominant, neutrophils were also seen in alveolar spaces, along with large numbers of red cells and edema fluid Fig. 1, A and B). The acute neutrophil-rich hemorrhagic alveolitis was especially prominent during the first $8 \mathrm{~h}$ after induction of the reaction. From $12 \mathrm{~h}$ and through the next 5 days the inflammatory exudate progressively disappeared so that on the 5th day lungs were essentially normal in appearance, both grossly and microscopically. In the "negative controls," that is, rats receiving rabbit IgG (lacking in antibody activity to BSA) intrabronchially and BSA intravenously, the his- tologic changes during the first $8 \mathrm{~h}$ consisted of small numbers of neutrophils scattered in alveolar spaces. These were few compared with the positive controls. No evidence of hemorrhage was found in the negative controls. This mild histologic reaction disappeared by $24 \mathrm{~h}$.

Permeability changes in lungs during acute alveolitis. The data in Table I show the extent of pulmonary injury, as measured by changes in permeability determined by accumulation of $\left[{ }^{125} \mathrm{I}\right] \mathrm{BSA}$ in the lung tissues. Two groups of rats (five each) were used, one receiving an intrabronchial injection of $1.0 \mathrm{mg}$ rabbit $\mathrm{IgG}$ which lacked anti-BSA activity while the second group received the same total amount of rabbit IgG which contained $250 \mu \mathrm{g} \mathrm{N}$ anti-BSA (as precipitating antibody). Both groups received $10 \mathrm{mg}$ BSA (with radioactive marker) intravenously. The difference in the permeability change was strikingly apparent: while the "negative" controls accumulated an equivalent of only $0.27 \mathrm{ml}$ blood radioactivity in their lungs, the "positive" controls had a mean accumulation of $1.32 \mathrm{ml}$ blood radioactivity in their lungs.

In order to determine if permeability changes in lungs would be quantitatively similar when a protein marker which was incapable of entering into the immunologic reaction was used, rats were injected simultaneously with $1 \mathrm{mg}$ human $\operatorname{IgG}$ (trace labeled with ${ }^{131} \mathrm{I}$ ) and BSA (trace labeled with ${ }^{125} \mathrm{I}$ ). Radioactivity accumulations in lungs were then measured (Table II). While the permeability changes in the positive controls in this experiment were not as great as those described in the preceding experiment, the data from these studies were nevertheless quite clear-cut; the permeability changes measured either by the immunologic reactant BSA or by the nonreactant protein, human $\mathrm{IgG}$, were very similar. It would therefore appear that most of the BSA accumulating in the lung reactions occurs as a result of permeability changes and that probably only a relatively small amount of BSA enters into a specific immunologic reaction (binding with antibody).

The time-course of the pulmonary reactions was studied with reference to permeability changes (measured by $\left[{ }^{125} \mathrm{I}\right] \mathrm{BSA}$ accumulation) in lungs of animals experiencing reactions over the course of 3-96 h. As is apparent in Table III, permeability changes were evident as early as $3 \mathrm{~h}$ and seemed to reach a maximum at $5 \mathrm{~h}$. The accumulation of radioactivity was always considered relative to the accumulation of radiolabeled BSA in negative control rats injected intrabronchially with saline. By $24 \mathrm{~h}$ the differences in accumulating radioactivity between the negative and positive controls was less apparent. From the 48 to the $96 \mathrm{~h}$ interval both the relative (to blood) as well as the actual amounts of radioactivity in lungs of both 
TABLE V

Accumulation of Serum C3 in Damaged Lungs

\begin{tabular}{ccc}
\hline \multicolumn{1}{c}{ Animal groups } & $n$ & $\begin{array}{c}\text { Concentration of } \\
{[126][\mathrm{C} 3 \text { in lungs }}\end{array}$ \\
\hline $\begin{array}{c}\text { Control (saline } \\
\text { into lungs) } \\
\begin{array}{c}\text { Experimental (antibody } \\
\text { into lungs) }\end{array}\end{array}$ & 6 & $0.27 \pm 0.12^{*}$ \\
\hline
\end{tabular}

* Expressed as milliliter equivalents of $\mathrm{C} 3$ radioactivity in 1.0 $\mathrm{ml}$ blood obtained at the time of sacrifice.

controls and experimental rats were similar. At these latter intervals retention of small amounts of BSA in the lung tissue could not be differentiated from continued delivery of the radioactive marker due to small but persistant changes in permeability.

Immunofluorescent studies. Lung tissue was examined for the presence of the reactant proteins: rabbit IgG (injected intrabronchially), BSA (injected intravenously), and rat C3. The data in Table IV show that both the antibody (rabbit $\operatorname{IgG}$ ) and BSA could be detected in lung tissue during the first $5 \mathrm{~h}$ of the reaction. The pattern of distribution of these proteins was irregular and focal, consistent with septal and alveolar distribution. Where rabbit IgG was found, BSA was also found (Fig. 2, A and B). Surprisingly, rat $\mathrm{C} 3$ could not be detected at any time in the pulmonary tissues (Table IV; Fig. 2C). By 8 h BSA and rabbit IgG became more difficult to detect and by $20 \mathrm{~h}$ all evidence by immunofluorescence of these proteins had disappeared (Table IV).

The inability to detect $\mathrm{C} 3$ in the pulmonary tissue could not be ascribed to a poor immunofluorescent preparation, since the same reagent detected C3 in developing intradermal Arthus reactions of the rat (Fig. 2D).

Accumulation of $\mathrm{C} 3$ in lung lesion. The inability to detect $\mathrm{C} 3$ by immunofluorescence in the developing pulmonary reactions of acute immunologic alveolitis raised the question as to whether C3 was being actively excluded from the reaction sites in lungs. To approach this question, rats were injected with a mixture containing a total of $200 \mu \mathrm{g}$ pure rat C3, of which approximately $10 \%$ was labeled with ${ }^{125} \mathrm{I}$. Accumulation of this protein in the developing pulmonary reactions was measured. The data in Table $\mathrm{V}$ indicate that whereas the accumulation of $\mathrm{C} 3$ in the negative control (saline intrabronchially) was in the same low range of other proteins (Tables I, II), nearly three times more C3 accumulated in the positive controls. The amount of C3 accumulating in the developing lung lesion is quantitatively similar to the amounts of BSA and human IgG (Table II). The failure to detect the $\mathrm{C} 3$ protein by immunofluorescence was unexplained but was obviously not due to the fact that rat $\mathrm{C} 3$ failed to find its way into lung tissue.

Abolition of pulmonary reactions in C3-depleted rats. In order to obtain further information on the possible role of $\mathrm{C} 3$ in the development of acute immunologic alveolitis, 11 rats were treated with the $\mathrm{C} 3$ inactivator isolated from cobra venom (17). This resulted in loss of measurable $\mathrm{CH}_{50}$ levels in sera of treated animals and the concomitant loss of immunochemical evidence for C3 in the sera of nearly all treated animals (Table VI). Pulmonary reactions were then induced in these animals. The results are shown in Table VII. The C3depleted rats grossly and histologically (Fig. 1, C) showed little evidence of acute hemorrhage compared with the C3-intact positive controls (Fig. 1, A and B). This was very evident when the lung homogenates were examined spectrophometrically (Table VII). Permeability changes in the lungs were low in saline-injected (intrabronchially) controls, with only $0.39 \mathrm{ml}$ blood radioactivity equivalent; whereas, the positive controls had a mean permeability change of $1.37 \mathrm{ml}$. On the other hand, the C3-depleted rats had a value between those of the positive and negative controls, with a mean value of $0.56 \mathrm{ml}$. That this was slightly higher than the value for the negative (saline-injected) control group was apparently due to the fact that four of the 11 rats had low but detectable levels of $\mathrm{C} 3$ as measured

TABLE VI

Complement Depletion after Treatment with C3 Inactivator

\begin{tabular}{ccc}
\hline Rat & Whole serum $\mathrm{CH}_{60}$ & $\mathrm{C} 3$ titer* \\
\hline Normal & 34 & 20 \\
1 & 42 & 20 \\
2 & 35 & 20 \\
3 & 37 & 20 \\
4 & & \\
& & \\
Depleted & $<4$ & 0 \\
1 & $<4$ & 4 \\
2 & $<4$ & 8 \\
3 & $<4$ & 0 \\
4 & $<4$ & 0 \\
5 & $<4$ & 0 \\
6 & $<4$ & 0 \\
7 & $<4$ & 2 \\
8 & $<4$ & 0 \\
9 & $<4$ & 0 \\
10 & $<4$ & 4 \\
11 & $<4$
\end{tabular}

* Reciprocal of serum dilution when C3 precipitin band in gel double diffusion disappeared. The zero values indicate that in neat serum no $\mathrm{C} 3$ could be demonstrated immunochemically. 
immunochemically (Table VI). Dermal Arthus reactions in these animals were either markedly or totally suppressed. These findings indicate that the development of acute immunologic alveolitis can be averted by prior treatment of rats with the $\mathrm{C} 3$ inactivator isolated from cobra venom.

Dependence of pulmonary reactions on available circulating neutrophils. The question arose as to whether the reaction of acute immunologic alveolitis was dependent on the availability of circulating neutrophils. Rats were depleted of neutrophils by the use of rabbit antibody specific to rat neutrophils. This resulted in a lowering of the neutrophil count to $<500 \mathrm{cells} / \mathrm{mm}^{8}$ blood. When neutrophil-depleted rats were subjected to the same procedures as the polymorphonuclear leukocyte (PMN)-intact animals, gross changes were not seen in the lungs of neutrophil-depleted rats; whereas, in the PMN-intact rats given anti-BSA intrabronchially the typical focal and confluent hemorrhages were seen, as described above. It was not possible to distinguish grossly or histologically tissues of the PMNdepleted rats from the negative (saline-injected) control rats (Fig. 1D). The permeability changes in the lungs of neutrophil-depleted rats were slightly less than those measured in the negative controls (Table VIII, 0.27 vs. $0.29 \mathrm{ml}$ ). In contrast, the positive control animals showed the characteristic increased permeability $(0.96 \mathrm{ml})$. These data indicate that neutrophils play an important role in the intensification of tissue injury in immunologic alveolitis, as judged by changes in permeability.

\section{DISCUSSION}

Studies of immunologically induced injury in the lung have certainly not kept pace with the progress in our understanding of immunologically induced injury in the kidney (19). Part of this problem is probably due to the difficulties in measuring changes in pulmonary function in experimental animals and the attendant

TABLE VII

Dependence of Pulmonary Damage on Availability of $C 3$

\begin{tabular}{cccc}
\hline Animal groups & $n$ & $\begin{array}{c}\text { Permeability } \\
\text { changes* }\end{array}$ & $\begin{array}{c}\text { Hemorrhage } \\
\text { (OD at 541 nm) }\end{array}$ \\
\hline $\begin{array}{c}\text { Controls (saline } \\
\text { into lungs) } \\
\begin{array}{c}\text { Experimental } \\
\quad(C 3-i n t a c t)\end{array}\end{array}$ & 4 & $0.39 \pm 0.05$ & \\
$\begin{array}{c}\text { Experimental } \\
\text { (C3-depleted) }\end{array}$ & 11 & $0.56 \pm 0.06$ & $0.565 \pm 0.119$ \\
\hline
\end{tabular}

* As measured by the accumulating [ $\left.{ }^{125} \mathrm{I}\right] \mathrm{BSA}$, according to Tables I-III.

$\ddagger$ Hemoglobin in lung homogenate.
TABLE VIII

Dependence of Pulmonary Damage on Availability of Neutrophils

\begin{tabular}{|c|c|c|}
\hline Animal groups & $n$ & $\begin{array}{l}\text { Permeability } \\
\text { changes* }\end{array}$ \\
\hline Controls (saline into lungs) & 8 & $0.29 \pm 0.08$ \\
\hline $\begin{array}{l}\text { Experimental, neutrophil-intact } \\
\text { (antibody into lungs) }\end{array}$ & 9 & $0.96 \pm 0.30$ \\
\hline $\begin{array}{l}\text { Experimental, neutrophil-depleted } \\
\text { (antibody into lungs) } \ddagger\end{array}$ & 9 & $0.27 \pm 0.04$ \\
\hline
\end{tabular}

* Measured by extravasation of radiolabeled BSA, as in Table I and described in text.

$\ddagger$ All animals had $<500$ neutrophils $/ \mathrm{mm}^{3}$ blood.

technical difficulties encountered in the surgical manipulations of the lung. Certainly our lack of clear understanding of immunopathologic mechanisms in the lung has been detrimental to interpreting biopsy and necropsy material coming from patients with a variety of inflammatory lung disorders, many of which parade under the general term "interstitial pneumonitis."

The type of lesion found in the experimental model described in this paper consists of an acute inflammatory exudate with edema, neutrophils, and hemorrhage. The localization of the cellular exudate is both interstitial and, to a less striking degree, intra-alveolar. The inflammatory cellular reaction appears to be relatively monophasic in that, following a heavy accumulation of neutrophils in the first 3-5 h, only a few mononuclear cells are seen at 12 and $24 \mathrm{~h}$. Most of the neutrophils simply disappear and are not replaced by another cell type. This is analogous to the reversed passive dermal Arthus reaction in skin in which accumulation of neutrophils leads to phagocytic uptake and destruction of the immune complex, resulting in a shutting off of the reaction $(13,20)$. To what extent the morphologic features of the lung reaction in our model might be altered by repeated exposure of the lung to immune complexes is not known. It seems likely that under such circumstances, a more chronic type of inflammatory cellular exudate might develop. If so, this would more closely mimic the inflammatory reaction seen frequently in human patients with interstitial pneumonitis.

The reaction described above might be considered an "Arthus reaction in the lung." The reaction is initiated by antigen diffusing from the circulation into a tissue bed containing deposits of antibody. The precise area of the reaction cannot be determined by the immunofluorescent techniques employed. The immune complexes may be initially forming in alveolar septal walls (i.e., primarily in an interstitial location) or along alveolar surfaces. Determination of the question will 
probably require immuno-electron micrographic approaches. Irregular granular deposits of antigen and antibody in alveolar and pulmonary interstitial areas certainly resemble those seen in the dermal Arthus reaction (13). Clearly, the ability to suppress the pulmonary inflammatory reaction with either $\mathrm{C} 3$ depletion or neutrophil depletion means that, like the dermal Arthus reaction, neutrophil accumulation requires availability of C3. Moreover, the major damage (reflected by hemorrhage to alveolar/capillary beds) appears to be the result of neutrophil accumulation with the subsequent delivery of a battery of enzymes, many lysosomal in nature, that can utilize structural proteins in the lungs as substrates. What cannot be explained at present is the precise role of $\mathrm{C} 3$ in the developing inflammatory reaction in the lung. The demonstration by radioactivity of $\mathrm{C} 3$ in the pulmonary tissues (Table VII) contrasts with an inability to demonstrate by immunofluoresence C3 in association with immune complexes. This suggests that the bulk of $\mathrm{C} 3$ is not tissue fixed and that it probably has been washed out during the immunofluorescent staining procedures. The inability to demonstrate $\mathrm{C} 3$ in tissue reactions by immunofluorescence could be due to insensitivity of the technique, or it could mean that the critical role of $\mathrm{C} 3$ is mediated by a fragment (such as C3a) or complex (such as $\mathrm{C} \overline{423}$ ) that is diffusable and not easily fixed to cell surfaces or immune complexes. Tissues were examined for the presence of $\mathrm{C} 3$ at a time beginning $3 \mathrm{~h}$ after injection of immune reactants. It is possible that by this interval C3 had already been fixed by the complexes in the tissues, and then removed by the infiltrating neutrophils $(13,19)$. However, against this possibility is the failure to detect $\mathrm{C} 3$ even in lungs of neutrophil-depleted rats.

It has to be admitted that in this model the main measurement of tissue damage is the quantitation of vascular permeability. While there is good evidence to indicate that the mediators of permeability and the leukotactic factors are structurally different and work independently, it is fairly clear from the data presented in this paper that most of the increase in permeability is really a reflection of vascular injury induced by the arrival of neutrophils (Table VIII). Perhaps a more direct quantitative measure of the inflammatory reaction would be the numbers of neutrophils in the lung, but in our hands this has proven to be extremely difficult because of technical problems. Bronchial wash out procedures, which have been monitored histologically, have failed to result in release of neutrophils in deeplying (alveolar) areas of lung, rendering this procedure unreliable as an approach to quantitating the cellular aspect of the inflammatory reaction. A search for enzymes in homogenized lung tissues likewise has not, for several technical reasons, been a successful approach to the quantitation of inflammatory cells in lung tissue. Consequently, we continue to measure permeability changes as the chief approach to the quantitation of lung injury.

In consideration of what marker should be used for the measurement of permeability changes, it was surprising to discover that regardless of whether or not the protein was able to enter into the immunologic reaction (BSA and C3, Tables II and VII, vs. human IgG, Table II), this made little difference in the result. As much nonimmunologically reactive protein (human IgG) accumulated in the pulmonary tissues as did the immunologically reactive protein ( $\mathrm{C} 3$ and $\mathrm{BSA}$ ). It can be calculated, on the basis of the predetermined binding ratios (at equivalence) for antigen and antibody, that the amount of antigen in lungs exceeds this value by at least 50 -fold, assuming that all the antibody were accessible to antigen, which does not seem likely.

These studies would appear to be among the first to provide definition of mediator systems involved in immunologic injury of the lung. The requirements for complement and neutrophils mirror the findings in the dermal Arthus reaction (13) and acute glomerulonephritis induced by heterologous antibody to glomerular basement membrane (15). Nevertheless there are some puzzling findings emerging from these studies, a major one being the precise role of $\mathrm{C} 3$ in the mediation of tissue injury. It will be important to determine if immune complex-induced injury in human lung also requires the participation of $\mathrm{C} 3$ and to what extent, if any, this protein is demonstrable in tissue lesions. Obviously this would have important implications for the interpretation of immunohistochemical results. Our current lack of knowledge about the outcome of repeated immunological results to the lung emphasizes the need for a careful and intensive study of the reaction of the lung to immunologic injury.

\section{ACKNOWLEDGMENTS}

This work was supported in part by National Institutes of Health grant AI-11526.

\section{REFERENCES}

1. McCombs, R. P. 1972. Diseases due to immunologic reactions in the lungs. N. Engl. J. Med. 286: 1186-1194, $1245-1252$.

2. Pepys, J. 1969. Hypersensitivity diseases of the lungs due to fungi and organic dusts. Monogr. Allergy. 4: 1-147.

3. Hagadorn, J. E., J. J. Vasquez, and T. R. Kinney. 1969. Immunopathologic studies of an experimental model resembling Goodpasture's syndrome. $\mathrm{Am}$. J. Pathol. 57: 17-30. 
4. Willoughby, W. F., and F. J. Dixon. 1970. Experimental hemorrhagic pneumonitis produced by heterologous anti-lung antibody. J. Immunol. 104: 28-37.

5. Koffler, D., J. Sandson, R. Carr, and H. G. Kunkel. 1969. Immunologic studies concerning the pulmonary lesions in Goodpasture's syndrome. Am. J. Pathol. 54: 293-305.

6. Opie, E. L. 1924. Inflammatory reaction of the immune animal to antigen (Arthus phenomenon) and its relation to antibodies. J. Immunol. 9: 231-245.

7. Fried, B. M. 1933. Allergic lobar pneumonia: experimental study. J. Exp. Med. 57: 111-119.

8. Cannon, P. R., T. E. Walsh, and C. E. Marshall. 1941. Acute local anaphylactic inflammation in the lungs. $\mathrm{Am}$. J. Pathol. 17 : 777-784.

9. McKinnon, G. E., E. C. Andrews, Jr., R. H. Heptinstall, and F. G. Germuth, Jr. 1957. An immunohistochemic study of the occurrence of intravascular antigen-antibody precipitation and its role in anaphylaxis in the rabbit. Bull. Johns Hopkins Hosp. 101: 258-271.

10. Eskensay, A. 1971. Immunomorphology of experimental Arthus phenomenon of the lung. Rev. Immunol. (Paris). 35: 85-101.

11. Richerson, H. B., F. H. F. Cheng, and S. C. Bauserman. 1971. Acute experimental hypersensitivity pneumonitis in rabbits. Am. Rev. Respir. Dis. 104: 568-575.

12. Eastham, W. N., and H. K. Muller. 1972. Changes in guinea-pig lungs following the inhalation of powdered egg albumin. Pathology. 4 : 235-241.
13. Ward, P. A., and C. G. Cochrane. 1965. Bound complement and immunologic injury of blood vessels. $J$. Exp. Med. 121: 215-234.

14. Helmkamp, R. W., R. L. Goodland, W. F. Bale, I. L. Spar, and L. E. Mutschler. 1960. High specific activity iodination of gamma-globulin with iodine-131 monochloride. U. S. A. E. C. Res. Dev. Rep. UR. 568: 1-18.

15. Cochrane, C. G., E. R. Unanue, and F. J. Dixon. 1965. A role for polymorphonuclear leukocytes and complement in nephrotoxic nephritis. J. Exp. Med. 122: 99-116.

16. Hill, J. H., and P. A. Ward. 1969. C3 leukotactic factors produced by a tissue protease. J. Exp. Med. 130: 505-518.

17. Ballow, M., and C. G. Cochrane. 1969. Two anticomplementary factors in cobra venom: hemolysis of guinea pig erythrocytes by one of them. J. Immunol. 103: 944 952.

18. Hill, J. H., and P. A. Ward. 1971. The phlogistic role of C3 leukotactic fragments in myocardial infarcts of rats. J. Exp. Med. 133: 885-900.

19. Unanue, E. R., and F. J. Dixon. 1967. Experimental glomerulonephritis: immunological events and pathogenetic mechanisms. Adv. Immunol. 6: 1-90.

20. Cochrane, C. G., W. O. Weigle, and F. J. Dixon. 1959. The role of polymorphonuclear leukocytes in the initiation and cessation of the Arthus vasculitis. J. Exp. Med. 110: 481-494. 